\title{
The largest Lower Devonian placoderm - Antineosteus rufus sp. nov. from the Barrandian area (Czech Republic)
}

\author{
VALÉRIA VAŠKANINOVÁ \& PETR KRAFT
}

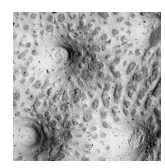

\begin{abstract}
Antineosteus rufus sp. nov. from the upper Emsian of the Czech Republic is described based on two fragments of large dermal plates discovered in the Suchomasty Limestone. The original length of the animal is inferred to have exceeded that of Tityosteus rieversae - the largest Lower Devonian placoderm recorded so far. The occurrence of A. rufus in the Prague Basin is consistent with other giant homostiids in several areas. These animals were apparently adapted to plankton-feeding, although they appeared in the conditions of collapsed diversity of the planktic communities during the "Devonian Nekton Revolution". This successful feeding strategy made them the first vertebrates occupying the nutrient-rich ecospace producing the largest animals up to the present. - Key words: Vertebrata, Placodermi, Antineosteus, Emsian, Barrandian area, nekton revolution.
\end{abstract}

VAŠKANINOVÁ, V. \& KRAFT, P. 2014. The largest Lower Devonian placoderm - Antineosteus rufus sp. nov. from the Barrandian area (Czech Republic). Bulletin of Geosciences 89(3), 635-644 (6 figures). Czech Geological Survey, Prague. ISSN 1214-1119. Manuscript received May 20, 2013; accepted in revised form April 12, 2014; published online June 4, 2014; issued June 9, 2014.

Valéria Vaškaninová, Czech Geological Survey, Geologická 6, 15200 Praha 5, Czech Republic, and Institute of Geology and Palaeontology, Charles University, Albertov 6, 12843 Praha 2, Czech Republic; valeria.vaskaninova@geology.cz. - Petr Kraft, Institute of Geology and Palaeontology, Charles University, Albertov 6, 12843 Praha 2, Czech Republic; kraft@natur.cuni.cz.

Placoderms make up a minor component of the fauna from the Devonian of the Barrandian area, Czech Republic. The Devonian of this area is globally renowned for its rich invertebrate fossil associations with brachiopods, trilobites, corals, bryozoans, goniatites, tentaculites, and conodonts as the significant faunal components. The Barrandian placoderms have been known since the second half of the $19^{\text {th }}$ century with the first description by Barrande (1872). The most abundant placoderm remains occur in the basal Lochkov Formation whilst higher up in the section they are rare. The section records a sudden overturn of the placoderm fauna at the time of the Pragian-Emsian transition. The less derived Acanthothoraci are fairly numerous in the Lochkovian and continue through to the Pragian, but in reduced numbers and body size (Gross 1958, 1959; Westoll 1967; Vaškaninová 2011). In the Emsian, members of the more derived order Arthrodira appeared in the Barrandian area, completely displacing the former acanthothoracid fauna (Vaškaninová \& Kraft in press). The majority of the arthrodire specimens can be assigned to the family Homostiidae (or clade Migmatocephala, see phylogenetic remarks), found in the Devonian strata of Europe, Morocco, Siberia, Spitsbergen, Greenland, Canada (Denison 1978) and southeastern Australia (White 1978).
The present paper is the first contribution to the revision of placoderm fauna from the Barrandian area. It describes a giant species, not only an extreme member of the vertebrate communities but also in the late Early Devonian marine ecosystems. Its importance is that the specimen occurs in sedimentary sequence with excellent stratigraphic control and in one of the key areas for Devonian stratigraphy because of global stratotypes as well as other sections.

\section{Material}

Although fossil fish remains are rare, as a result of sustained collecting throughout the $19^{\text {th }}$ and $20^{\text {th }}$ centuries, the National Museum in Prague (NM) now houses a large collection. In addition to a partly described historical collection from the $19^{\text {th }}$ century (Barrande 1872, Eastman 1897, Bayer 1905, Perner 1918) several collectors such as A. Schubert, F.J. Pecka, W. Kolář, R. Růžička and I. Chlupáč in the first half of the $20^{\text {th }}$ century were able to substantially add to the collections, when quarrying in the Barrandian area was still active (Perner 1918). 


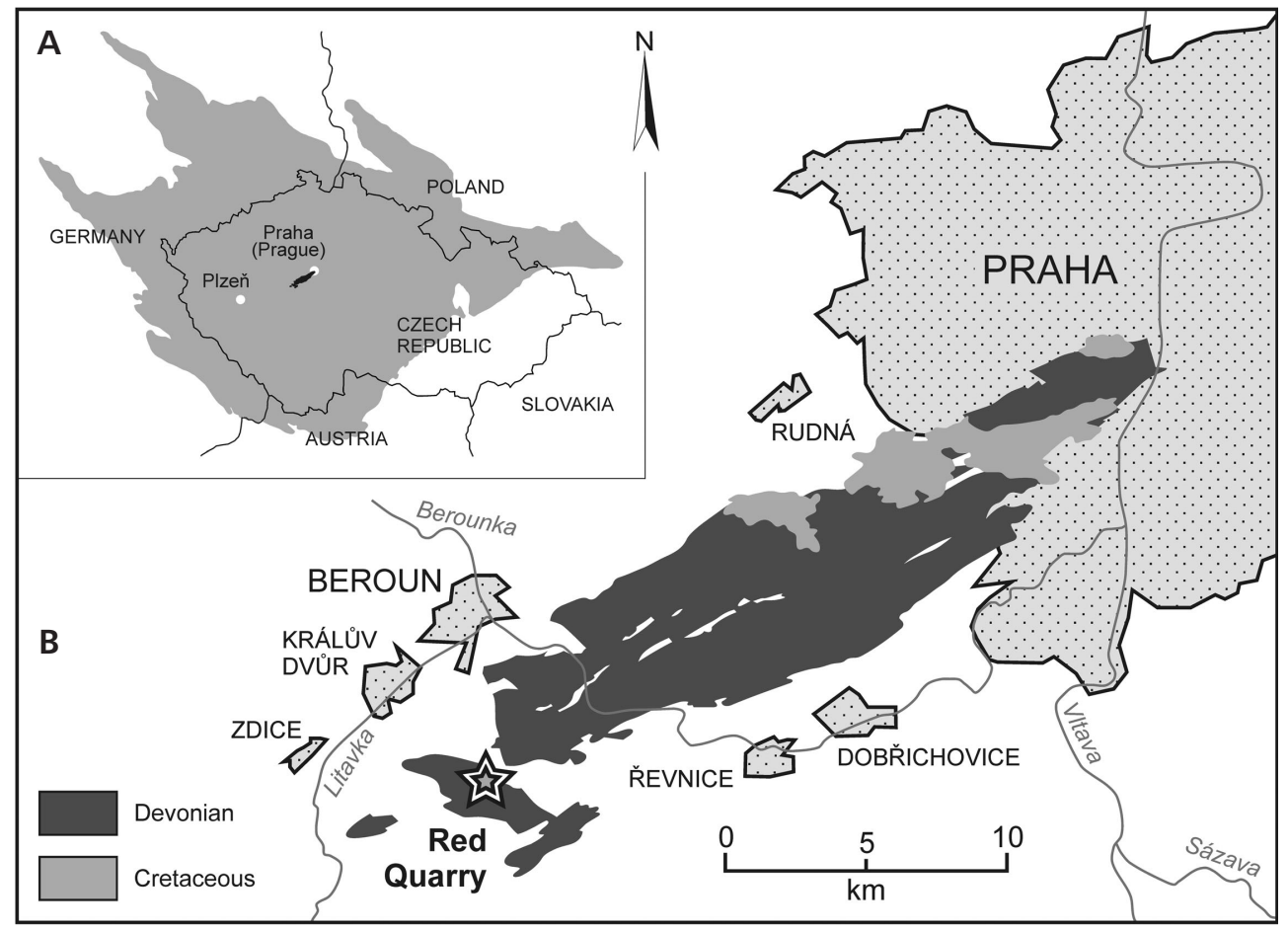

Figure 1. Sketch map of the Devonian in the Prague Basin. -A - location of Devonian sediments (black) in the central part of the Bohemian Massif (grey shaded) on the territory of the Czech Republic. • B - simplified map of the Devonian distribution with the fossil site marked with an asterisk. Some rivers, towns and cities are selected with respect to the overall picture; tectonics is omitted; only the significant marine Cretaceous cover is displayed, younger continental units are omitted.

The specimens described here were discovered in the Červený lom (Red Quarry) near the villages of Suchomasty and Koněprusy, south west of Prague (GPS coordinates $\left.49^{\circ} 54^{\prime} 38^{\prime \prime} \mathrm{N}, 14^{\circ} 4^{\prime} 36^{\prime \prime} \mathrm{E}\right)$, Czech Republic (Fig. 1). Both specimens were donated to the National Museum by J. Kácha, a private fossil collector, in the 1990's, however, as the specimens were given to him by the Červený lom quarry workers the exact layer is not known (J. Kácha, oral communication). However, acid digestion (see below) has provided age diagnostic conodonts.

Each specimen comprises a single dermal plate, where the bone structure is preserved in its original thickness without compression, atop a limestone slab. The surface structure of the dermal plates is well preserved including the ornamentation of dermal tubercles. One specimen (Lc 126) is partly exfoliated and exhibits its inner bone layers partly exposed in the thickest area of the plate. Both plates are incomplete, especially their margins which are broken off in an irregular manner. This mode of preservation is as a result of a post-mortem transport across a short distance.

The studied material is deposited in the collections of the National Museum in Prague.

\section{Geological and palaeontological settings}

The studied fossils were discovered at "Červený lom" Quarry near Suchomasty (Fig. 1) in the Suchomasty Limestone, a local facies of the upper Emsian Daleje-Třebotov
Formation (Fig. 2) in the Koněprusy area (for the description of the locality see Chlupáč et al. 1979, Chlupáč 1993, Berkyová 2009 and Berkyová et al. 2009; a detailed analysis of various aspects was provided by Dieken 1996). It is a lectostratotype of the Suchomasty Limestone (Chlupác 1981; for the section of the entire sequence see Chlupáč et al. 1979, fig. 14) and exposes a complete sequence of the so-called Suchomasty Marble, used as a decorative stone. It comprises reddish and grey bioclastic (mainly crinoidal) and micritic, mostly well-bedded limestones with common stromatactis structures (e.g. Havlíček \& Kukal 1990; for microfacies and some other characteristics see Dieken 1996, Koptíková 2011 and Vodrážková et al. 2013; the stromatactis structures were studied in detail by Kukal 1972, recently by Dieken 1996, Hladil 2005 and Hladil et al. 2006), its thickness is 20-30 m. Coarser detritus dominates both the lowest and uppermost parts of the sequence (Chlupáč et al. 1979, Chlupáč 1998, Koptíková 2011). The sediments were deposited on the weathered and corroded surface of the Koněprusy Reef, represented by the Koněprusy Limestone (e.g. Chlupáč 1976, fig. 1; Chlupáč et al. 1979, fig. 15; Havlíček \& Kukal 1990, fig. 2; Chlupáč 1998, fig. 68), covering the former reef flat and lagoon of this submerging "dead" reef after a short gap from the early to mid Emsian. The Suchomasty Limestone reflects a shallow, purely marine environment with a high level of turbulence and rapid changes between low and high-energy stages of the current intensity (Chlupáč et al. 1979, Chlupáč 1998, Havlíček \& Kukal 1990) but probably below the storm-wave (Vodrážková et al. 2013). 


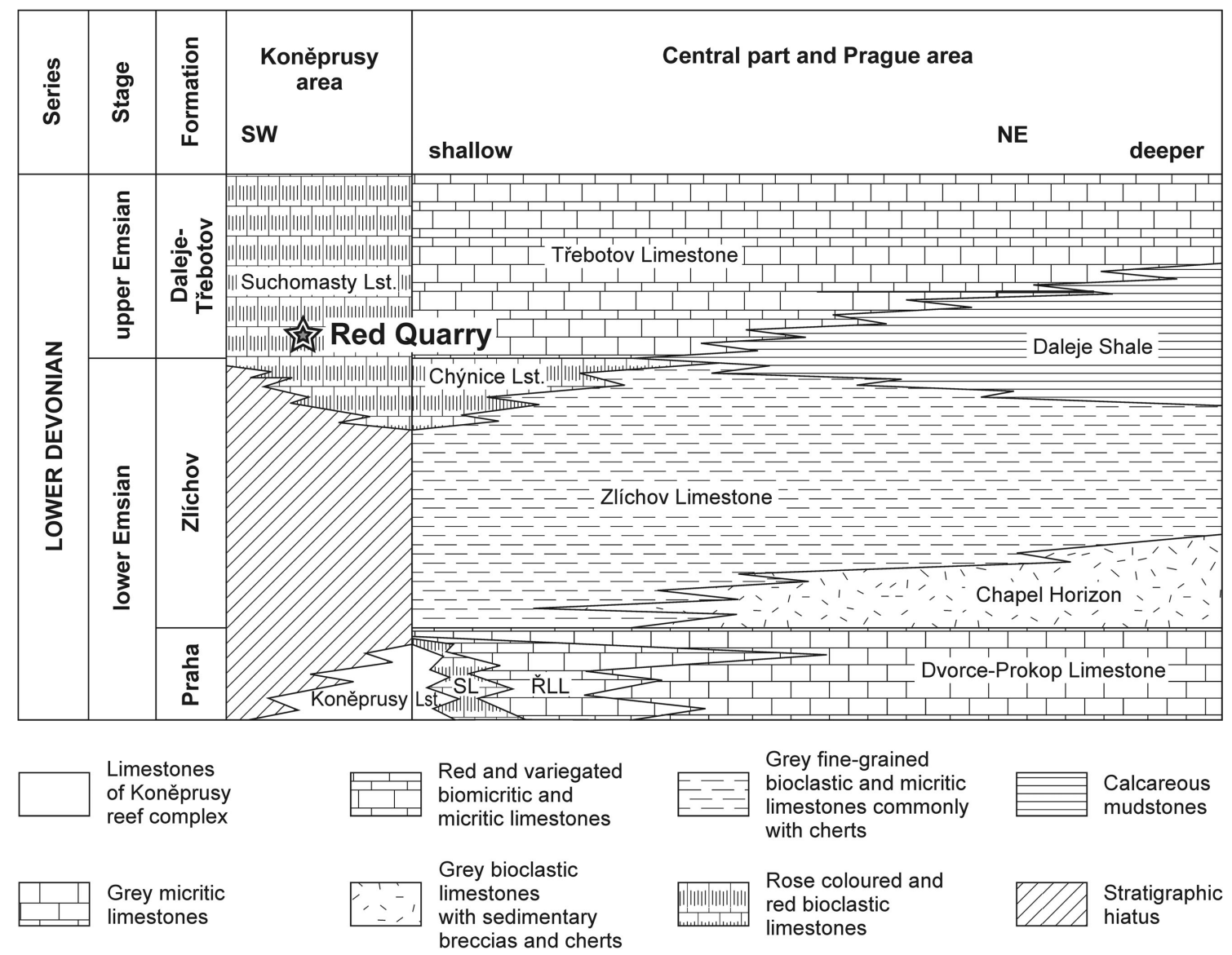

Figure 2. Stratigraphic chart of the Emsian in the Prague Basin with the position of the fossil site marked with an asterisk (modified after Budil et al. 2013). Abbreviations: Lst. - Limestone, SL - Slivenec Limestone, ŘLL - Ǩeporyje-Loděnice Limestone.

The fauna of the Suchomasty Limestone at the Červený lom Quarry is rich in benthos. The invertebrate fauna is abundant in certain layers and contains mainly echinoderms, and also tentaculites, ostracods, trilobites (Chlupáč et al. 1979; Chlupáč 1993, 1998) and brachiopods (Chlupáč et al. 1979, Havlíček \& Kukal 1990, Mergl \& Vodrážková 2012) as the significant components (for all groups see Dieken 1996). Only a few taxa of microflora and microfaunal foraminifera were identified by Dieken (1996). Lack of other microelements, calcispheres and peloids (in contrast to its deeper water equivalent - the Třebotov Limestone) was proved by Berkyová \& Munnecke (2010).

The Suchomasty Limestone at the quarry has been constrained to the interval of the Novakia elegans-N. cancellata- $N$. richteri-N. holynensis tentaculite zones (Chlupáč et al. 1979, Ferrová et al. 2012) and the Polygnathus laticostatus- $P$. serotinus- $P$. costatus patulus conodont zones (Chlupáč et al. 1979, Dieken 1996, Berkyová 2009). No associated index fossils, such as tentaculites, were found on the slabs on which both placoderm specimens occur. A piece of rock from the specimen Lc 125 was digested using acetic acid and several fragments of conodonts were dis- covered in the residue. S. Vodrážková (oral communication) determined the elements as Belodella sp., which is not stratigraphically diagnostic and a single fragment of Icriodus beckmanni (subspecies unknown) indicative of the serotinus Zone (Dalejan, upper Emsian). In addition, according to Berkyová (2009), I. beckmanni is confined to this stratigraphical level in the Prague Basin and thus the studied placoderm remains, at least specimen Lc 125, can be assigned to the serotinus Zone.

\section{Systematic palaeontology}

Class Placodermi McCoy, 1848

Order Arthrodira Woodward, 1891

Suborder Brachythoraci Gross, 1932

Family Homostiidae Jaekel, 1903; emend. Mark-Kurik \& Carls, 2004

\section{Genus Antineosteus Lelièvre, 1984a}

Type species. - Antineosteus lehmani Lelièvre, 1984a. 


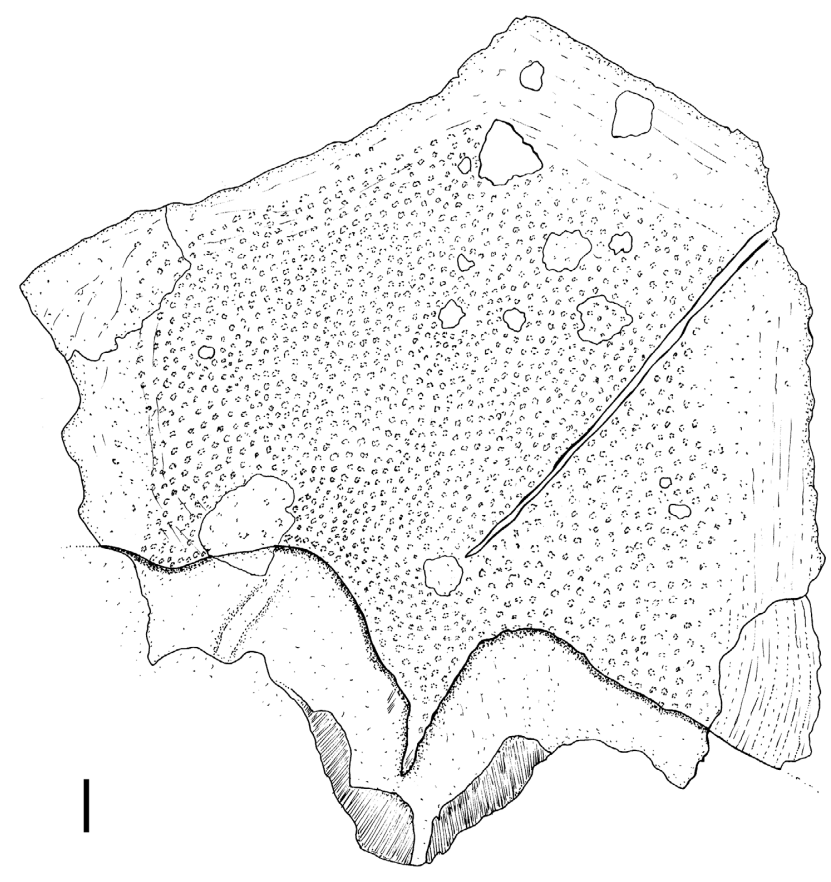

Figure 3. Antineosteus rufus sp. nov. NM Lc 125, holotype. Right central plate. Scale bar $1 \mathrm{~cm}$.

Emended diagnosis. - The genus Antineosteus belongs to the family Homostiidae (Brachythoraci) and is characterized by the pineal plate with two lateral expansions reaching towards the preorbital plates. The dorsal margin of the orbital notch is formed by the lateral margin of a single postorbital plate. The anterior and lateral margins of the central plates are straight. The supraorbital sensory line is absent on the central plates. Dermal ornament consists of round tubercles with tips separated by a shallow ridge.

Remarks. - Antineosteus was described as a monospecific genus and no separate diagnoses were provided by Lelièvre (1984a). For the purpose of describing a new species we erected the genus diagnosis of selected features observed by Lelièvre (1984a) extended by our new observations.

Species assigned. - Antineosteus lehmani Lelièvre, 1984a; Antineosteus rufus sp. nov.

Geographic and stratigraphic occurrence. - Morocco, Algeria and Czech Republic; Upper Emsian (Dalejan).

\section{Antineosteus rufus sp. nov.}

Figures 3-6

Derivation of name. - From the Latin rufus (red) after the colour of the limestone as well as the name of the type locality - the Red Quarry (Červený lom).
Holotype. - Nearly complete right central head shield plate NM Lc 125 figured in Figs 3, 5B, 6.

Type locality. - Red Quarry near Suchomasty (Czech Karst, Czech Republic).

Material. - Right central plate (NM Lc 125), right anterior dorsolateral plate (NM Lc 126).

Diagnosis. - The following combination of characters: right central plate of approximately equal width and length; absence of pit lines on the central plates; the suture between both central plates curved; the posterior process of the central plate narrow and more acutely pointed than in A. lehmani; the dermal tubercles smaller and sparsely distributed than in A. lehmani.

Description. - Central plate (C). The anterior and lateral margins of the right central plate of the head shield (Figs 3, 5B) are not preserved. Thus, the original size of the plate was larger than the preserved area, with the preserved width and length, both approximately $13 \mathrm{~cm}$. The medial suture with the left central plate is poorly preserved, but appears to be curved.

The well-preserved posteromesial margin illustrates the overlap areas, where the nuchal and paranuchal plates sutured. It indicates that the anterior margin of the nuchal plate was concave. In the overlap area for the nuchal plate a transverse thickening is preserved, extending towards the right anterior lobe of the nuchal plate. The posterolateral overlap area was covered by the paranuchal plate; its shape indicates an acute anterior margin of the plate.

Lateromesially to the sharp posterior process of the central plate separating the overlap areas for the nuchal and paranuchal plates runs the central sensory line canal. It is preserved as two parallel grooves, partly exposed, because the sensory line was originally porous. No trace of supraorbital sensory line or pit lines is observable on the surface of the plate. The average thickness of the plate is $1 \mathrm{~mm}$, reaching maximum $5 \mathrm{~mm}$ anteromesially.

Anterior dorsolateral plate (ADL). The right anterior dorsolateral plate (Figs 4, 5A) is slender anteriorly and widens gradually posteriorly. The anterior part of the plate along with the articular condyle has the inner bone structure exposed forming a spiny projection in the midline. The articular condyle points dorsally almost in the same axis as the surface of the plate. The articular area is partly preserved; being long, slender and concave ventrally. The preserved dorsal margin of the ADL is straight and a trace of the overlap area for the median dorsal plate is visible. Most of the ventrolateral part of the anterior dorsolateral along with the overlap areas for the surrounding plates is not preserved. The length of the plate fragment is $16 \mathrm{~cm}$. 
The main sensory line canal runs medially. Its preserved posterior part is straight, and formed as one shallow groove. The maximum thickness at the posterodorsal margin of the plate reaches $5 \mathrm{~mm}$.

Both plates are covered with dermal ornament, although this has suffered some damage. In a few areas the typical arthrodire ornament of round tubercles with a shallow ridge separating the tip (detail Fig. 6) is visible. Towards the outer margins of both plates, the tubercles tend to be arranged in lines. The ornament on the uppermost dermal bone layer of the anterior and lateral margins of the central plates has been eroded away revealing linear ridges, possibly lines of arrested growth. The sensory lines cross through some of the tubercles.

Remarks. - The preserved outline of the anterior margin of the nuchal plate indicates that the left central plate was narrower than the right one (a situation comparable to the skull roof of Antineosteus lehmani Lelièvre, 1984a and Tityosteus rieversae Gross, 1960).

Both plates indicate a homostiid affinity: 1) Large Coccosteina with broad, depressed head and trunk shields (Denison 1978). This character is supported by the position of the articular condyle, its axis following the anterior margin of the plate, which supports a nearly horizontal position of the plate (Young 2005, p. 217) and thus of the dorsal part of the trunk shield as well as the skull roof. It indicates a dorsoventrally compressed armour of A. rufus. 2) Narrow anterior borders of the $\mathrm{PNu}$ and $\mathrm{Nu}$ plates, the strong posterolateral extensions of the central plates (Young 2004).

The determination of the new plates to the genus Antineosteus is supported by the characters in common with A. lehmani: the shape of the central plate, the course of the central sensory line canal and the dermal ornament. The shape of the anterior part of ADL and the outline of the overlap area for the median dorsal plate on the preserved part of the ADL of A. rufus are also very similar.

The course of the main sensory line on the ADL is straighter than on A. lehmani (compare Lelièvre 1984a) and runs medially on the contrary to the lc of A. lehmani that runs parallel to the dorsal margin of the plate. However, this character can be highly variable. The notable size difference between the two species cannot be used as a diagnostic character either as this may represent continuous variation.

However, the posterior outline of the central plate is more curved than on A. lehmani with a longer and sharper posterior process (in addition to a more acute anterior outline of the paranuchal plate). Another character which justifies the erection of a new species is the absence of pit-lines on the central plate of $A$. rufus.

The absence of the supraorbital canals on the central plates is a typical character shared by the primitive brachythoracids Homostius, Burrinjucosteus (White 1978),

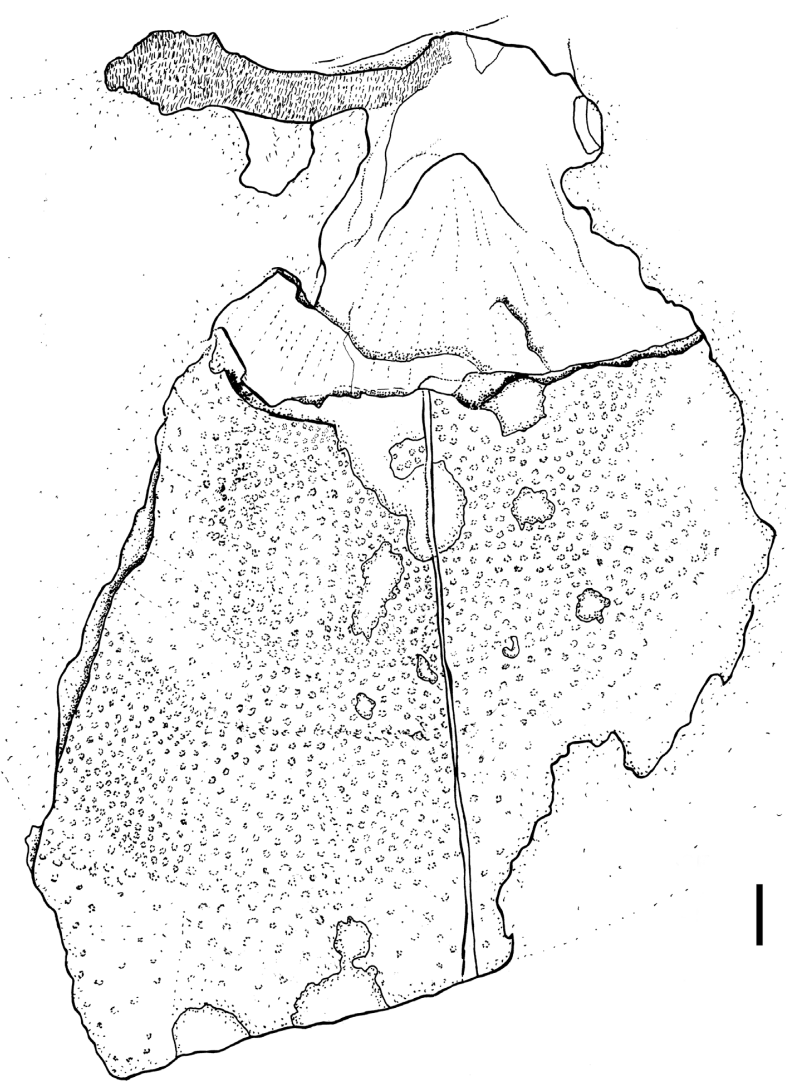

Figure 4. Antineosteus rufus sp. nov. NM Lc 126. Right anterior dorsolateral plate. Scale bar $1 \mathrm{~cm}$.

Dhanguura (Young 2004) as well as most dolichothoracids (Lelièvre 1984a). However, it is not considered a phylogenetically significant character, rather a plesiomorphy of the clade Taemasosteus-Antineosteus (Lelièvre 1984a) or a reversion of evolution (Young 1981). The extension of supraorbital canals onto the centrals is listed as one of the brachythoracid characters by Denison (1984).

The anterior dorsolateral plate of Homostius (Heintz 1934) has a different shape with the main lateral line running parallel to the ventral edge of the plate (Denison 1978). In general, Homostius is unique among homostiids in a different skull roof pattern due to the dorsal position of the orbits. Burrinjucosteus asymetricus also shows characters similar to $A$. rufus, such as the absence of supraorbital sensory lines on the $\mathrm{C}$ plates or the outline of the anterior margins of the $\mathrm{Nu}$ and PNu (White 1978). Taemasosteus, despite of the presence of supraorbital canals on the $\mathrm{C}$ plates, has a very similar shape of the ADL plate (White 1978).

Phylogenetic remarks. - Most authors have dealt with the relationship and evolution among the whole group of placoderms (e.g. Denison 1983, Goujet \& Young 1995), the arthrodires (Denison 1984) or rather the more advanced brachythoracid arthrodires (Young 1981, Carr 1991, Trinajstic \& Dennis-Bryan 2009). 
The genus Antineosteus was originally included in the family Homostiidae (Lelièvre 1984a after the definition proposed by Young 1981). According to the more recent phylogenetic analysis of Lelièvre (1995, fig. 14) it was included among a "primitive brachythoracid" clade Migmatocephala (erected by White \& Toombs 1972 on the basis of "mixed" characters between arctolepids, brachythoracids and pachyosteomorphs), sharing a synapomorphy of absent posterior ventral plates of the thoracic armour (Lelièvre 1995, character 36) with Homostius. This condition results in the posterior opening of the pectoral fenestra. Young (2003) places Atlantidosteus provisionally among the migmatocephalans as a sister taxon of Homostius, on the basis of an elongate suborbital lamina of the suborbital plate. This character, as well as the characters linking Antineosteus and Homostius to the remaining migmatocephalans (Tityosteus and Taemasosteus) and Holonema (Lelièvre et al. 1990), is not observable on the preserved material of $A$. rufus.

Some characters are detectable on the material despite its poor state of preservation: character 1 of Lelièvre (1995) "dermal plates of the skull-roof with overlapping surfaces", character 8 "shape of the anterior nuchal margin on the dorsal surface: convex", character 12 "paranuchal plate process onto the central plate determining a lateral lobe", character 17 "posterior lobe of the central plate protruding between the nuchal and paranuchal plates" and character 44 "supraorbital sensory line on the central plate: absent". However, Trinajstic \& Dennis-Bryan (2009) have observed all these characters, except character 1, showing polymorphism within the eubrachthytoracid arthrodires.

Remarks on body size. - Gross (1960) estimated the total length of $T$. rieversae to a maximum of $250 \mathrm{~cm}$ but he had only the posterior part of the skull roof available. Thus, he inferred the size from the proportions of Coccosteus and mentioned the possible range of the skull roof of $T$. rieversae from 35 up to $50 \mathrm{~cm}$ in length without knowledge of the dimensions of the anterior part. He however admits, that the position and shape of the nuchal and paranuchal plates of $T$. rieversae resemble a member of Homostiidae where those plates are prolonged compared to Eubrachythoraci (up to two thirds of the whole head shield). Later, Otto (1992) described a new material of $T$. rieversae containing the anterior head shield plates associating the genus more closely with the Homostiidae (length of central plate $19 \mathrm{~cm}$ and ADL $11 \mathrm{~cm}$; total length of the head shield approximately $45 \mathrm{~cm}$ ). Therefore the body dimensions proposed by Gross (1960) were overestimated.

The size and shape of the plate Lc 126 indicates an anterior dorsolateral plate of a larger specimen than Lc 125 as only approximately one half of the right ADL is preserved. However, the completely preserved ADL of T. rieversae is shorter than the preserved part of the ADL of the larger specimen of $A$. rufus n. sp. We calculated the skull size based on comparison with the reconstruction of the complete head shield of A. lehmani and size ratios of its plates (Lelièvre 1984a) and the dimensions and plate pattern of T. rieversae listed by Otto (1992). The potential allometric growth changes were omitted because plates of large, i.e. presumably adult specimens were compared. In addition, the known ontogenetic data indicate that length proportions of most plates were constrained in different growth stages despite of allometry in other directions (e.g. Werdelin \& Long 1986, Cloutier 2010). The length of the skull roof of $A$. rufus specimen Lc 125 based only on the size of the fragment of the $\mathrm{C}$ plate is at least $45 \mathrm{~cm}$. However, we assume the fragment represents only a half of the original plate. In such case the length of the skull roof must be doubled. The calculations based on the fragmentary specimen Lc 126 resulted even in a larger dimension of the skull roof. Minimum size considering the present fragment length would be some $70 \mathrm{~cm}$. However, it is evident (see above) that at least one half of the plate is missing. Thus the skull should exceed $1 \mathrm{~m}$ in length.

According to the calculated dimensions of the skull, the total length of the fish when it was alive is inferred to have exceeded 3 metres (considering the extreme calculations and in accordance with Gross 1960 even 6 metres), which makes it the largest Lower Devonian placoderm known so far. It was much larger than the Australian (Wee Jasper, New South Wales) Dhanguura and Cathlesichthys, considered by Young (2004) to be comparable in size to Tityosteus rieversae. The large brachythoracid Confractamnis johnjelli from the Broken River area in Queensland (Australia) originates most probably from Middle Devonian strata (Young 2005).

\section{Discussion}

The earliest record of the Homostiidae (sensu Young 2004) is of Emsian age. The youngest, Homostius sulcatus (Kutorga, 1837) (taxonomic assignment according to MarkKurik pers. comm. 2013), is from the lower Givetian of Laurussia (Baltic area, Scotland, Canada; Mark-Kurik 1992). These primitive brachythoracid arthrodires are known from the Lower Devonian strata of various regions: northern and eastern continental margins of Gondwana - Rhineland, Aragón and Minusinsk Basin (Tityosteus, Mark-Kurik \& Carls 2004); the Emsian of south eastern Australia (Goodradigbeeon, Burrinjucosteus, Taemasosteus, White 1978; Dhanguura, Cathlesichthys, Young 2004), Morocco and Algeria (Antineosteus, Atlantidosteus; Lelièvre 1984a, 1984b, 1988) and Czech Republic (Antineosteus; studied herein), and from Laurussia - Spitsbergen (Homostius; Mark-Kurik \& Carls 2004, fig. 5) and Severnaya Zemlya (Mark-Kurik 1991). In these areas they occupied mostly shallow tropical 


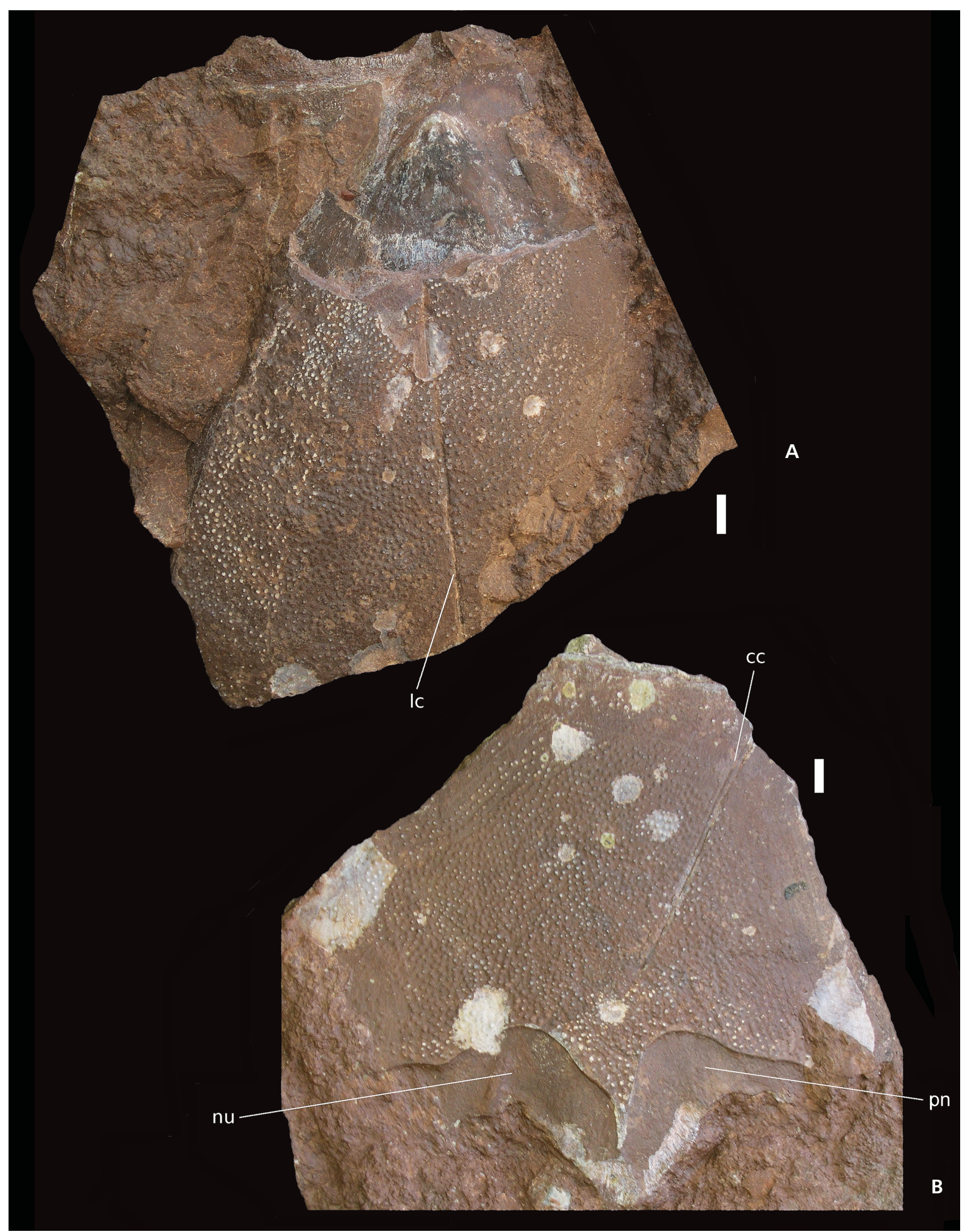

Figure 5. Antineosteus rufus sp. nov. • A - NM Lc 126. Right anterior dorsolateral plate. • B - NM Lc 125, holotype. Right central plate. Scale bar $1 \mathrm{~cm}$. Abbreviations: $\mathrm{cc}$ - central sensory line canal, lc - main sensory line canal, pn - overlap area for the paranuchal plate, nu - overlap area for the nuchal plate. 


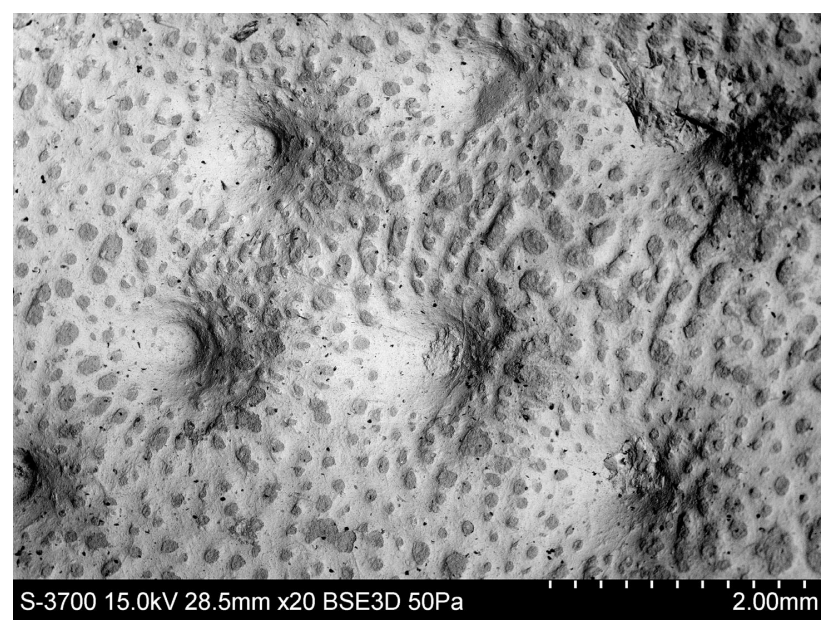

Figure 6. Antineosteus rufus sp. nov. NM Lc 125, holotype. SEM detail of dermal sculpture from the medial margin of the plate.

to subtropical marine environments (White 1978, Young 2003) with good connections to open seas (Mark-Kurik \& Young 2003). Lelièvre (1984a) discussed the possible migration routes along the northern (Turkey, Iran, Afghanistan) or southern (South America) continental margins of Gondwana. The occurrence of A. rufus supports a northern migration route rather than southern. Considering the occurrence of the coeval and relative genus Atlantidosteus (Young 2003) in the Emsian of Morocco on the southern hemisphere and in the Eifelian of Australia (Queensland) that was close to the palaeoequator, makes this pattern of distribution more probable. The distribution of the seemingly endemic faunas (Denison 1984) could be in connection with the maximum transgression in the Emsian (Young 1987) thus related to the Daleje Event (House 1985, Chlupáč \& Kukal 1988, Ferrová et al. 2012 and references therein). Mark-Kurik \& Young (2003) note that the presence of large fishes in various strata is an indicative of palaeoclimatic conditions rather than of the palaeogeography.

The homostiids in general possessed edentulous jaws and were large sized (Mark-Kurik \& Carls 2004). This combination of features is typical for planktivorous vertebrates. Such a mode of life was supposed by Denison (1978) for three arthodire genera including Homostius. Mark-Kurik (1992) compared the feeding strategy and the body size of this taxon to the modern whale shark. MarkKurik \& Carls (2004) discussed a microphagous feeding behaviour of Homostius and Antineosteus with respect to the direct fossil evidence of their toothless jawbones. In the latter, the preserved inferognathal of A. lehmani is toothless or covered by dermal tubercles (Lelièvre 1984a, fig. 14, pl. IV. C, D). A. rufus and other large arthodires can be reasonably supposed as planktivorous (suspension feeders) as well even though their jawbones are unknown yet.

The occurrence of the giant A. rufus in the Emsian of the Prague Basin, in addition to other giant placoderms in the Lower Devonian worldwide suggests abundant food resources. It is significant that the very large homostiids such as Tityosteus rieversae Gross, 1960, Dhanguura johnstoni Young, 2004, Cathlesichthys weejasperensis Young, 2004, and Antineosteus rufus sp. nov., among which A. rufus is the largest, occurred globally in the Emsian and appeared almost coevally. This occurrence is considered to be another hitherto overlooked aspect (not to be confused with dominating giant predaceous placoderms in the Late Devonian; see Signor \& Brett 1984) of a global event labelled as the Devonian Nekton Revolution (Klug et al. 2010).

The mentioned appearance of several giant homostiids during the Early Devonian represents an initial occupation of the free ecospace, which was repeatedly refilled by large bony fishes in most of the Mesozoic and by baleen whales, some rays and sharks in the Cenozoic (Friedman et al. 2010). Large homostiids, including A. rufus, are thus the oldest members of this ecological guild of large-bodied planktivorous vertebrates. These specialised forms appeared in such a stage of vertebrate evolution that allowed an effective reflection of the planktivourous feeding habit on the body size. This evolutionary advantage appeared in period of general plankton decline in diversity (Klug et al. 2010, Fig. 1). However, the occurrence of these placoderms is an indirect evidence that the water column was rich in nutrients and e.g. larvae and fry had to be abundant (naturally, not analysed by Klug et al. 2010).

\section{Acknowledgments}

We are grateful to B. Ekrt (National Museum, Prague) for his kind help with the material and the SEM study. Some important comments on the stratigraphical position of the samples provided S. Vodrážková, L. Ferrová (both Czech Geogical Survey, Prague) and P. Lukeš (Prague). J. Frýda (Czech Geological Survey, Prague) gave valuable remarks improving the manuscript. We are very grateful to H. Lelièvre, D. Goujet (both MNHN, Paris) and E. Mark-Kurik (TUT, Tallinn) for their consultations on the systematic part and for providing access to the comparative material in their collections. We thank T. Prrikryl (Academy of Sciences of the Czech Republic) for valuable comments on the modern fish faunas and literature resources. We are grateful to P. Belaňová for the hand drawings and Š. Manda (Czech Geological Survey, Prague) for providing the template for Fig. 1B. L. Laibl is thanked for helping with the computer drawings, J. Vodička for assistance with the field works and $\breve{S}$. Rak for consultations (all Faculty of Science, Charles University in Prague). We kindly thank K. Trinajstic and E. Mark-Kurik for their helpful reviews of the manuscript and language corrections. The study was funded by the Charles University in Prague grant projects: GAUK no. 278011, SVV261203 and PRVOUK P44. This paper is a contribution to the International Geoscience Programme (IGCP) Project 591 - The Early to Middle Paleozoic Revolution. 


\section{References}

BARRANDE, J. 1872. Système silurien du centre de la Bohême. 1. Supplément au Vol. I. Trilobites, Crustacées divers et Poissons. 640 pp. Prague et Paris.

BAYER, F. 1905. Katalog českých fossilních obratlovců (Fossilia vertebrata Bohemiae). 102 pp. Česká akademie císaře Františka Josefa pro vědy, slovesnost a umění, Praha.

BerkyovÁ, S. 2009. Lower-Middle Devonian (upper EmsianEifelian, serotinus-kockelianus zones) conodont faunas from the Prague Basin, the Czech Republic. Bulletin of Geosciences 84(4), 667-686. DOI 10.3140/bull.geosci.1153

Berkyová, S., Koptíková, L., Slavík, L., FrÝda, J. \& Hladil, J. 2009. Excursions Part 2: Czech Republic. Berichte der Geologischen Bundesanstalt 79, 61-69.

BerkyovÁ, S. \& MunNeCKe, A. 2010. "Calcispheres" as a source of lime mud and peloids - evidence from the early Middle Devonian of the Prague Basin, the Czech Republic. Bulletin of Geosciences 85(4), 585-602.

DOI 10.3140/bull.geosci.1206

Budil, P., Crônier, C., Manda, S̆., Fatka, O., Laibl, L. \& Bignon, A. 2013. Juvenile phacopid trilobites from the Prague Basin (Czech Republic). Paläontologische Zeitschrift 87(2), 219-234. DOI 10.1007/s12542-012-0157-x

CARR, R.K. 1991. Reanalysis of Heintzichthys gouldii (Newberry), an aspinothoracid arthrodire (Placodermi) from the Famennian of nothern Ohio, with a rewiew of brachythoracid systematics. Zoological Journal of the Linnean Society 103, 349-390. DOI 10.1111/j.1096-3642.1991.tb00909.x

Chlupáč, I. 1976. The Bohemian Lower Devonian Stages and remarks on the Lower-Middle Devonian boundary. Newsletter in Stratigraphy 5, 167-189.

ChluPÁČ, I. 1981. Stratigraphic terminology of the Devonian in Central Bohemia (Barrandian area, Czechoslovakia). Věstník Ústředního ústavu geologického 56, 263-270.

Chlupéč, I. 1993. Geology of the Barrandian. A Field Trip Guide. 163 pp. Senckenberg-Buch 69, Waldemar Kramer, Frankfurt am Main.

Chlupáč, I. 1998. Devonian, 101-133. In Chlupéč, I., HavlíčeK, V., KŘiž, J., Kukal, Z. \& S̆Torch, P. (eds) Palaeozoic of the Barrandian (Cambrian to Devonian). Czech Geological Survey, Prague.

Chlupáč, I. \& Kukal, Z. 1988. Possible global events and the stratigraphy of the Palaeozoic of the Barrandian (Cambrian Middle Devonian, Czechoslovakia). Sborník geologických věd, Geologie 43, 83-146.

Chlupéč, I., Lukeš, P. \& ZikmundovÁ, J. 1979. The Lower/Middle Devonian boundary beds in the Barrandian area, Czechoslovakia. Geologica et Palaeontologica 13, 125-156.

Cloutier, R. 2010. The fossil record of fish ontogenies: Insights into developmental patterns and processes. Seminars in Cell \& Developmental Biology 21, 400-413. DOI 10.1016/j.semcdb.2009.11.004

Denison, R.H. 1978. Placodermi, 1-128. In Schultze, H.-P. (ed.) Handbook of Paleoichthyology, Vol. 2. Gustav Fischer Verlag, Stuttgart.

Denison, R.H. 1983. Further consideration of placoderm evolution. Journal of Vertebrate Paleontology 3(2), 69-83. DOI 10.1080/02724634.1983.10011962

Denison, R.H. 1984. Further consideration of the phylogeny and classification of the Order Arthrodira (Pisces: Placodermi). Journal of Vertebrate Paleontology 4(3), 396-412.

DOI 10.1080/02724634.1984.10012018

DieKEN, G. 1996. Karbonatmikrofazies, Paläoökologie und Genese der Stromatactis-Strukturen des Suchomasty- und des basalen Acanthopyge-Kalksteins im Barrandium (Tschechische Republik). Aachener Geowissenschaftliche Beiträge 19, 1-116 + Supplement 17 pp.

EAstman, C.R. 1897. On the relations of certain plates in the Dinichthyds, with descriptions of new species. Bulletin of the Museum of Comparative Zoology 31(2), 19-44.

Ferrová, L., Frýda, J. \& Lukeš, P. 2012. High-resolution tentaculite biostratigraphy and facies development across the Early Devonian Daleje Event in the Barrandian (Bohemia): implications for global Emsian stratigraphy. Bulletin of Geosciences 87(3), 587-624. DOI 10.3140/bull.geosci.1336

Friedman, M., Shimada, K., Martin, L.D., Everhart, M.J., Liston, J., Maltese, A. \& Triebold, M. 2010. 100-millionyear dynasty of giant planktivorous bony fishes in the Mesozoic seas. Science 327, 990-993.

DOI 10.1126/science.1184743

Goujet, D. \& Young, G. 1995. Interrelationships of Placoderms revisited. Geobios 19, 89-95.

DOI 10.1016/S0016-6995(95)80093-X

Gross, W. 1932. Die Arthrodira Wildungens. Geologische und Paläontologische Abhandlungen 19, 5-61.

Gross, W. 1958. Über die älteste Arthrodiren-Gattung. Notizblatt des Hessischen Landesamtes für Bodenforschung zu Wiesbaden 86, 7-30.

Gross, W. 1959. Arthrodiren aus dem Obersilur der Prager Mulde. Palaeontographica A 113, 1-3, 1-35.

Gross, W. 1960. Tityosteus n. gen., ein Riesenarthrodire aus dem rheinischen Unterdevon. Paläontologische Zeitung 34, 263-274. DOI 10.1007/BF02986870

Havlíček, V. \& KuKal, Z. 1990. Sedimentology, benthic communities, and brachiopods in the Suchomasty (Dalejan) and Acanthopyge (Eifelian) Limestones of the Koněprusy area (Czechoslovakia). Sborník geologických věd, Paleontologie 31, 105-205.

Heintz, A. 1934. Revision of the Estonian Arthrodira. Part I. Family Homostiidae Jaekel. Archiv für die Naturkunde Estlands I, 10 (4), 180-290.

HLADIL, J. 2005. The formation of stromatactis-type fenestral structures during the sedimentation of experimental slurries a possible clue to a 120-year-old puzzle about stromatactis. Bulletin of Geosciences 80(3), 193-211.

HLADIL, J., RƯŽIČKA, M. \& KopTíKOVÁ, L. 2006. Stromatactis cavities in sediments and the role of coarse-grained accessories. Bulletin of Geosciences 81(2), 123-146.

DOI 10.3140/bull.geosci.2006.02.123

House, M.R. 1985. Correlation of mid-Palaeozoic ammonoid evolutionary events with global sedimentary perturbations. Nature 313, 17-22. DOI 10.1038/313017a0

JAEKEL, O. 1903. Ueber Placodermen aus dem Devon. Berliner Deutsche Geologische Zeitschrift 55.

Klug, C., Kröger, B., Kiessling, W., Mullins, G.L., Servais, T., FrÝd, J., Korn, D. \& Turner, S. 2010. The Devonian nekton revolution. Lethaia 43, 465-477.

DOI 10.1111/j.1502-3931.2009.00206.x

KoptíkovÁ, L. 2011. Precise position of the Basal Choteč event 
and evolution of sedimentary environments near the Lower-Middle Devonian boundary: The magnetic susceptibility, gamma-ray spectrometric, lithological, and geochemical record of the Prague Synform (Czech Republic). Palaeogeography, Palaeoclimatology, Palaeoecology 304, 96-112. DOI 10.1016/j.palaeo.2010.10.011

KuKAL, Z. 1972. Open-space structures in the Devonian limestones of the Barrandian (Central Bohemia). Časopis pro mineralogii a geologii 16, 345-362.

Kutorga, S. 1837. Zweiter betrag für Geognosie und Paläontologie Dorpat's und seiner nächsten Umgebungen. 51 pp. St. Petersburg.

LeLIÈvre, H. 1984a. Antineosteus lehmani n. g., n. sp., nouveau Brachythoraci du Dévonien inferiéur du Maroc présaharien. Remarques sur la paléobiogéographie des Homostéides de l'Emsien. Annales de Paléontologie 70(2), 115-158.

Lelièvre, H. 1984b. Atlantidosteus hollardi n. g., n. sp., nouveau Brachythoraci (Vertébrés, Placodermes) du Dévonien inférieur du Maroc présaharien. Bulletin du Muséum national d'histoire naturelle 6(2), 197-208.

LeLIÈvre, H. 1988. Nouveau matériel d'Antineosteus lehmani Lelièvre, 1984 (Placoderme, Brachythoraci) et d'Acanthodiens du Dévonien inférieur (Emsien) d'Algérie. Bulletin du Muséum national d'histoire naturelle 10, 287-302.

LELIÈVRE, H. 1995. Description of Maideria falipoui n. g., n. sp., a long snouted brachythoracid (Vertebrata, Placodermi, Arthrodira) from the Givetian of Maider (South Morocco), with a phylogenetic analysis of primitive brachythoracids. Bulletin du Muséum national d'histoire naturelle 17, 163-207.

Lelièvre, H., Goujet, D. \& Henn, A. 1990. Un nouveau spécimen d'Holonema radiatum (Placodermi, Arthrodira) de Dévonien moyen de la région d'Oviedo, Espagne. Bulletin $d u$ Muséum national d'histoire naturelle 12, 53-83.

Mark-Kurik, E. 1991. Contribution to the correlation of the Emsian (Lower Devonian) on the basis of placoderm fishes. Newsletters on Stratigraphy 25(1), 11-23.

MARK-KURIK, E. 1992. The inferognathal in the Middle Devonian arthrodire Homostius. Lethaia 25, 173-178. DOI 10.1111/j.1502-3931.1992.tb01382.x

Mark-Kurik, E. \& CARls, P. 2004. Tityosteus, a marine fish (Arthrodira, Homostiidae) from the Emsian of Aragón, Spain, and its distribution. Revista Española de Paleontología 19(2), 139-144.

Mark-Kurik, E. \& Young, G.C. 2003. A new buchanosteid arthrodire (placoderm fish) from the Early Devonian of the Ural Mountains. Journal of Vertebrate Paleontology 23(1), 13-27. DOI 10.1671/0272-4634(2003)23[13:ANBAPF]2.0.CO;2

McCoy, F. 1848. On some new fossil fishes of the Carboniferous period. Annals and Magazine of Natural History 2, 1-10. DOI 10.1080/03745485809496133

Mergl, M. \& VodrážKovÁ, S. 2012. Emsian-Eifelian lingulate brachiopods from the Daleje-Třebotov Formation (Třebotov and Suchomasty limestones) and the Choteč Formation (Choteč and Acanthopyge limestones) from the Prague Basin; the Czech Republic. Bulletin of Geosciences 87(2), 315-332. DOI 10.3140/bull.geosci.1298

Отто, M. 1992. Ein Neufund des brachythoracen Arthrodiren Tityosteus rieversi aus dem unterdevonischen Hunsrück- schiefer des rheinischen Schiefergebirges. Neues Jahrbuch für Geologie und Paläontologie, Abhandlungen 187, 53-82.

Perner, J. 1918. Vorläufiger Bericht über die Fischfauna des böhmischen Obersilur und die Fossilienverteilung in den F1-Schichten. Centralblatt für Mineralogie, Geologie und Paläontologie, 318-322.

Signor III, P.W. \& Brett, C.E. 1984. The mid-Paleozoic precursor to the Mesozoic marine revolution. Paleobiology 10(2), 229-245.

Trinajstic, K. \& Dennis-Bryan, K. 2009. Phenotypic plasticity, polymorphism and phylogeny within placoderms. Acta Zoologica 90, Suppl. 1, 83-102.

DOI 10.1111/j.1463-6395.2008.00363.x

VAŠKANINOVÁ, V. 2011. Notes on a new revision of the genus Radotina (Placodermi). Ichthyolith Issues, Special Publication 12, 51-52.

VAŠKaninOvÁ, V. \& KRAFT, P. in press. Dynamics of placoderm distribution in the Prague Basin (Czech Republic). GFF. DOI 10.1080/11035897.2014.880510

Vodrážková, S., Frýda, J., Suttner, T.J., Koptíková, L. \& Tonarová, P. 2013. Environmental changes close to the Lower-Middle Devonian boundary, the Basal Choteč event in the Prague Basin (Czech Republic). Facies 59(2), 425-449. DOI 10.1007/s10347-012-0300-x

Werdelin, L. \& Long, J.A. 1986. Allometry in the placoderm Bothriolepis canadensis and its significance to antiarch evolution. Lethaia 19(2), 161-169.

DOI 10.1111/j.1502-3931.1986.tb00727.x

Westoll, T.S. 1967. Radotina and other tesserate fishes. Zoological Journal of the Linnean Society 47, 311, 83-98. DOI 10.1111/j.1096-3642.1967.tb01397.x

White, E.I. 1978. The larger arthrodiran fishes from the area of the Burrinjuck Dam, N.S.W. Transactions of the Zoological Society of London 34, 149-262.

DOI 10.1111/j.1096-3642.1978.tb00374.x

White, E.I. \& ToomBs, H.A. 1972. The Buchanosteid arthrodires of Australia. Bulletin of the British Museum (Natural History) Geology 22(5), 379-419.

Woodward, A.S. 1891. Catalogue of Fossil Fishes. Part 2. 567 pp. British Museum (Natural History), London.

YounG, G.C. 1981. A new early Devonian brachythoracid (placoderm fishes) from the Taemas - Wee Jasper region of New South Wales. Alcheringa 5, 245-271. DOI 10.1080/03115518108566994

YounG, G.C. 1987. Devonian vertebrates of Gondwana. American Geophysical Union, 41-50.

YounG, G.C. 2003. A new species of Atlantidosteus Lelièvre, 1984 (Placodermi, Arthrodira, Brachythoraci) from the Middle Devonian of the Broken River area (Queensland, Australia). Geodiversitas 25(4), 681-694.

YounG, G.C. 2004. Large brachythoracid arthrodires (Placoderm Fishes) from the Early Devonian of Wee Jasper, New South Wales, Australia, with a discussion of basal brachythoracid characters. Journal of Vertebrate Paleontology 24(1), 1-17. DOI 10.1671/1942-1

YounG, G.C. 2005. A new Middle Devonian arthrodire (Placoderm Fish) from the Broken River Area, Queensland. Records of the Australian Museum 57(2), 211-220. DOI 10.3853/j.0067-1975.57.2005.1443 